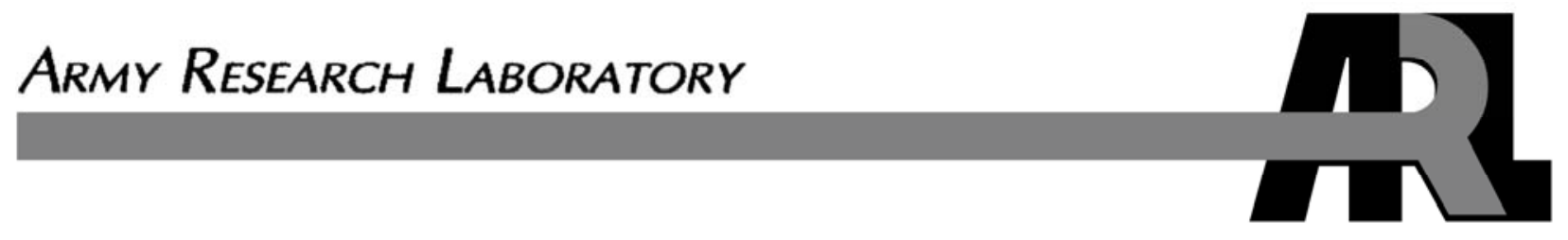

\title{
Endurance Testing of Redesigned Tab Spring for MI-RAMS System
}

\author{
by Mark R. Probst
}

ARL-TN-0388

April 2010 


\section{NOTICES}

\section{Disclaimers}

The findings in this report are not to be construed as an official Department of the Army position unless so designated by other authorized documents.

Citation of manufacturer's or trade names does not constitute an official endorsement or approval of the use thereof.

Destroy this report when it is no longer needed. Do not return it to the originator. 


\title{
Army Research Laboratory
}

Adelphi, MD 20783-1197

\section{Endurance Testing of Redesigned Tab Spring for MI-RAMS System}

\author{
Mark R. Probst \\ Sensors and Electron Devices Directorate, ARL
}




\section{REPORT DOCUMENTATION PAGE}

Public reporting burden for this collection of information is estimated to average 1 hour per response, including the time for reviewing instructions, searching existing data sources, gathering and maintaining the data needed, and completing and reviewing the collection information. Send comments regarding this burden estimate or any other aspect of this collection of information, including suggestions for reducing the burden, to Department of Defense, Washington Headquarters Services, Directorate for Information Operations and Reports (0704-0188), 1215 Jefferson Davis Highway, Suite 1204, Arlington, VA 22202-4302. Respondents should be aware that notwithstanding any other provision of law, no person shall be subject to any penalty for failing to comply with a collection of information if it does not display a currently valid OMB control number.

PLEASE DO NOT RETURN YOUR FORM TO THE ABOVE ADDRESS.

\begin{tabular}{|c|c|c|}
\hline $\begin{array}{l}\text { 1. REPORT DATE (DD-MM-YYYY) } \\
\text { April } 2010\end{array}$ & $\begin{array}{l}\text { 2. REPORT TYPE } \\
\text { Final }\end{array}$ & $\begin{array}{l}\text { 3. DATES COVERED (From - To) } \\
\text { April } 2009\end{array}$ \\
\hline \multirow{3}{*}{\multicolumn{2}{|c|}{$\begin{array}{l}\text { 4. TITLE AND SUBTITLE } \\
\text { Endurance Testing of Redesigned Tab Spring for MI-RAM }\end{array}$}} & 5a. CONTRACT NUMBER \\
\hline & & 5b. GRANT NUMBER \\
\hline & & 5c. PROGRAM ELEMENT NUMBER \\
\hline \multirow{3}{*}{\multicolumn{2}{|c|}{$\begin{array}{l}\text { 6. AUTHOR(S) } \\
\text { Mark R. Probst }\end{array}$}} & 5d. PROJECT NUMBER \\
\hline & & 5e. TASK NUMBER \\
\hline & & 5f. WORK UNIT NUMBER \\
\hline \multicolumn{2}{|c|}{ 7. PERFORMING ORGANIZATION NAME(S) AND ADDRESS(ES) } & 8. PERFORMING ORGANIZATION \\
\hline \multicolumn{2}{|c|}{$\begin{array}{l}\text { U.S. Army Research Laboratory } \\
\text { ATTN: RDRL-SES-S } \\
2800 \text { Powder Mill Road } \\
\text { Adelphi, MD 20783-1197 }\end{array}$} & $\begin{array}{l}\text { REPORT NUMBER } \\
\text { ARL-TN-0388 }\end{array}$ \\
\hline \multicolumn{2}{|c|}{ 9. SPONSORING/MONITORING AGENCY NAME(S) AND ADDRESS(ES) } & 10. SPONSOR/MONITOR'S ACRONYM(S) \\
\hline \multirow{2}{*}{\multicolumn{2}{|c|}{$\begin{array}{l}\text { Project Manager, Close Combat Systems } \\
\text { Attn: SFAE-AMO-CCS } \\
\text { Picatinny, NJ 07806-5000 }\end{array}$}} & \\
\hline & & $\begin{array}{l}\text { 11. SPONSOR/MONITOR'S REPORT } \\
\text { NUMBER(S) }\end{array}$ \\
\hline
\end{tabular}

Approved for public release; distribution unlimited.

\section{SUPPLEMENTARY NOTES}

\section{ABSTRACT}

When a Magneto-Inductive Remote Activation Munition System (MI-RAMS) production contractor proposed an alternate tab spring design to avoid scrapping a large number of obsolete arming tabs, an endurance test plan was developed and conducted in order to qualify the alternate design. Successful testing resulted in reductions in cost and delivery impact.

15. SUBJECT TERMS

Arming tab, tab spring, rotor, spring pin, endurance testing

\section{SECURITY CLASSIFICATION OF:}

\begin{tabular}{l|l|l|}
\hline a. REPORT & b. ABSTRACT & c. THIS PAGE \\
Unclassified & Unclassified & Unclassified \\
\hline
\end{tabular}

17. LIMITATION

OF ABSTRACT

UU
18. NUMBER OF PAGES

22 19a. NAME OF RESPONSIBLE PERSON Mark R. Probst

19b. TELEPHONE NUMBER (Include area code) (301) 394-2199 


\section{Contents}

List of Figures $\quad$ iv

$\begin{array}{lr}\text { 1. Introduction } & 1\end{array}$

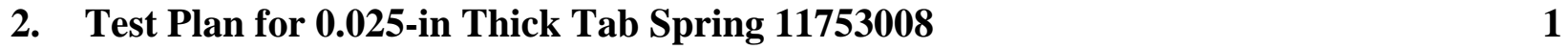

3. $\quad$ Test Data to be Recorded 3

4. Notes on Test Hardware, Test Rationale, and Photo-documentation 4

5. Test Data $\quad 4$

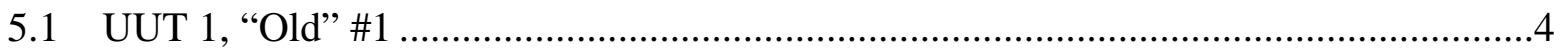

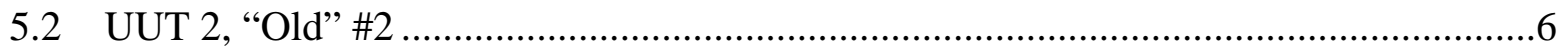

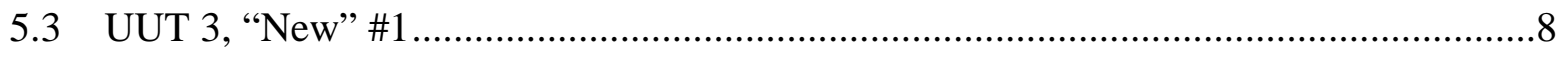

5.4 UUT 4, "New" \#2 .........................................................................................

6. Results and Conclusions $\quad 11$

6.1 “Old” Arming Tabs with 0.025-in-thick Tab Springs ...............................................11

6.2 "New” Arming Tabs with 0.025-in-thick Tab Springs .............................................11

7. Recommendations 12

$\begin{array}{ll}\text { Distribution List } & 14\end{array}$ 


\section{List of Figures}

Figure 1. Diagram of the "hump of interlock" height..........................................................2

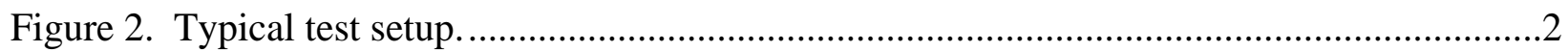

Figure 3. Drawing showing the red features we inspected. ....................................................

Figure 4. Post-test photo 1 for the UUT 1, “Old” \#1 test. ..........................................................5

Figure 5. Post-test photo 2 for the UUT 1, “Old” \#1 test. .........................................................6

Figure 6. Post-test photo 1 for the UUT 2, “Old” \#2 test. ........................................................

Figure 7. Post-test photo 2 for the UUT 2, “Old” \#2 test. .......................................................7

Figure 8. Post-test photo 1 for the UUT 3, “New” \#1 test........................................................8

Figure 9. Post-test photo 2 for the UUT 3, “New” \#1 test.......................................................

Figure 10. Post-test photo 1 for the UUT 4, "New” \#2 test......................................................10

Figure 11. Post-test photo 1 for the UUT 4, "New" \#2 test......................................................10

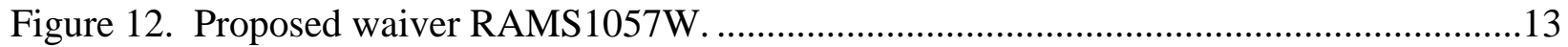

Figure 13. Diagram showing the "hump interlock" area.......................................................14 


\section{Introduction}

A necessary Magneto-Inductive Remote Activation Munition System (MI-RAMS) design change by the U.S. Army Research Laboratory (ARL) rendered obsolete a large number of previously built arming tabs (a flat hinged handle, which is lifted up and rotated in order to arm the MI-RAMS device). An MI-RAMS contractor proposed a simple change to the tab spring (a small curved spring, which interacts with the arming tab) that would allow the obsolete parts to be used "as is" and avoid significant cost and system delivery impact. ARL was tasked to plan and execute qualification testing of the proposed tab spring change to supplement the limited testing that had been performed by the contractor.

\section{Test Plan for $\mathbf{0 . 0 2 5}$-in Thick Tab Spring 11753008}

The following is the test plan used in this effort:

1. All testing was conducted at room temperature as the change in mechanical properties for the 17-7 RH 950 material from cold to hot usage limits $\left(-30\right.$ to $\left.+135^{\circ} \mathrm{F}\right)$ is not significant for this application.

2. We installed the unit under test (UUT), a rotor with a 0.025 -in thick tab spring 11753008 , an arming tab, and a spring pin, into a RAMS-B receiver lid with a spacing washer and an E-clip.

3. We then clamped the lid in a vise, positioned the rotor in the "Armed" position and the arming tab in the "down against the lid" position.

4. We checked for proper arming tab height (0.100 in maximum above the "hump" of the interlock spring — see figure 1 ) and recorded the initial value. 


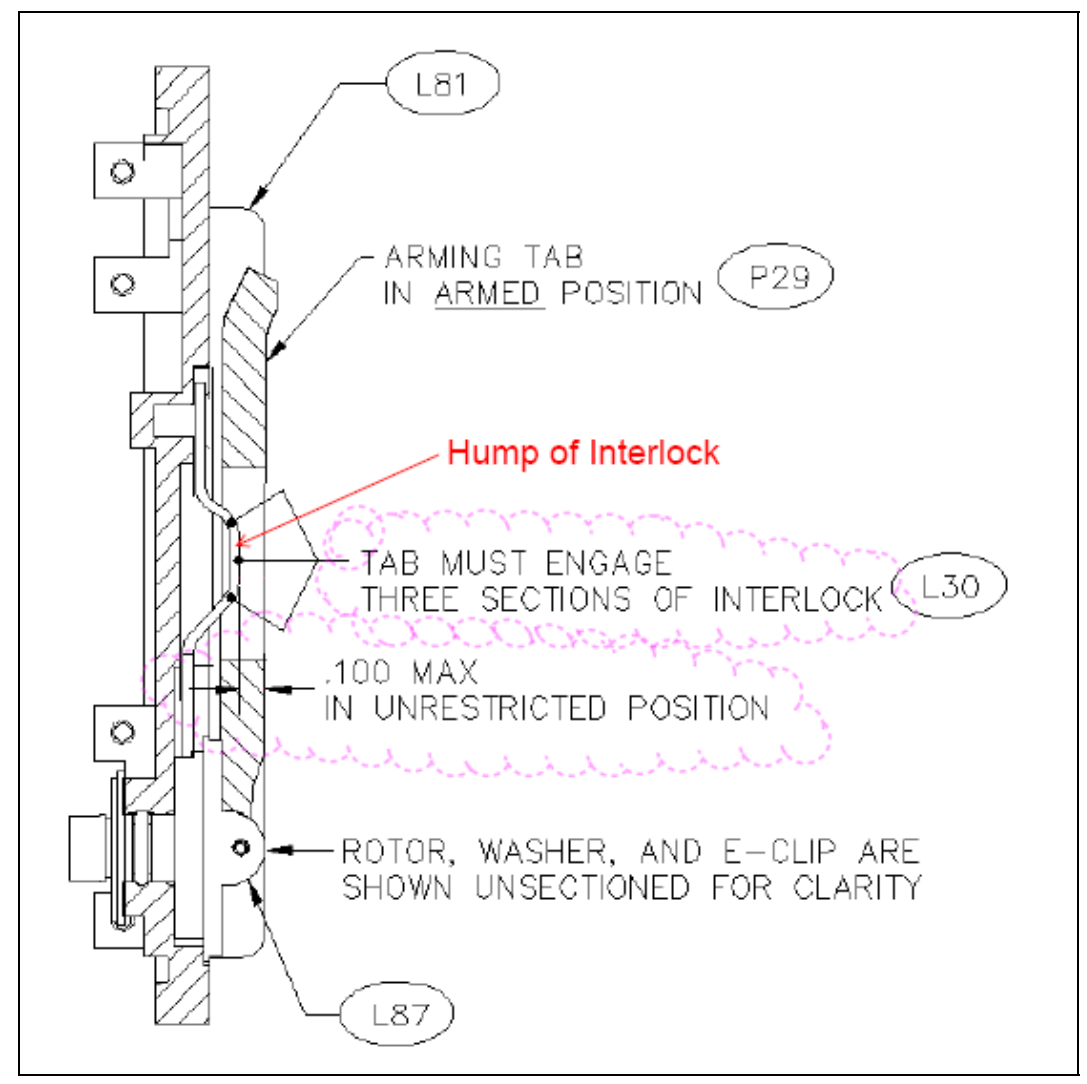

Figure 1. Diagram of the "hump of interlock" height.

5. We rotated the arming tab $180^{\circ}$ and then put it back to the "down against the lid" position.

6. The process was repeated for 2000 cycles, though we only repeated step 4 every 25 cycles.

Figure 2 shows the typical test setup.

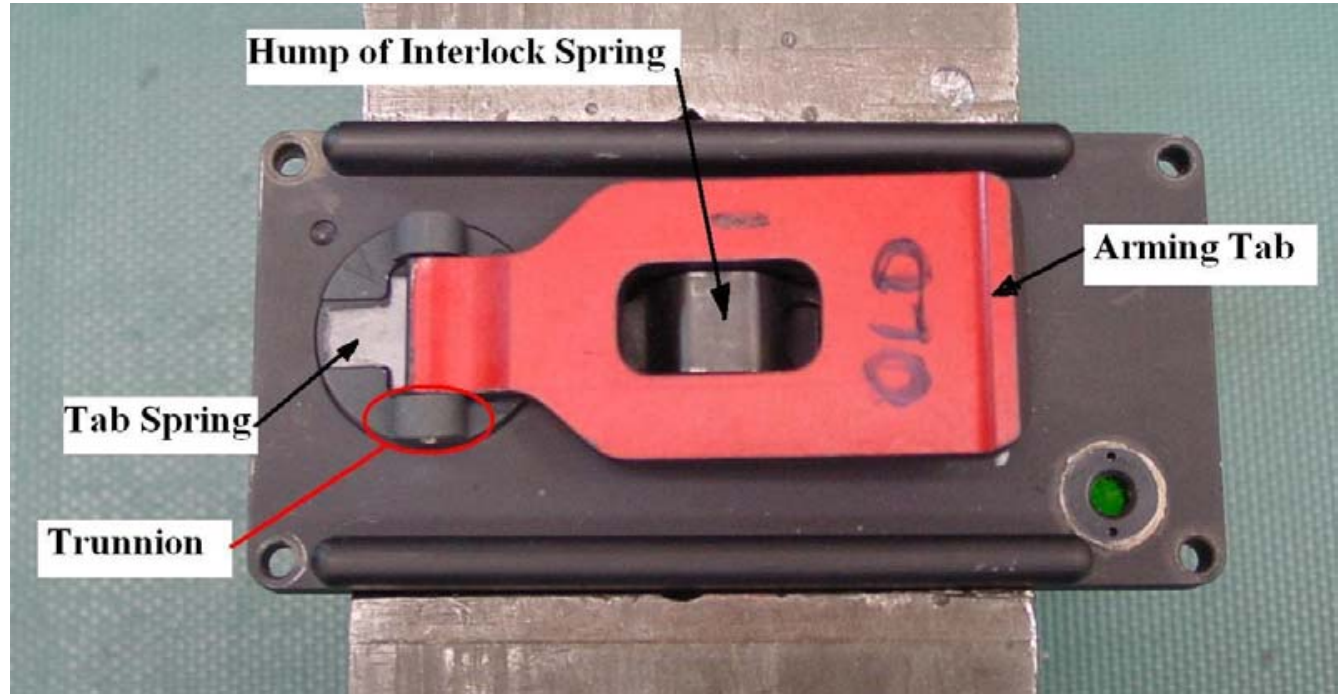

Figure 2. Typical test setup. 


\section{Test Data to be Recorded}

These steps outline the test data that was required by the test plan.

1. We recorded the arming tab height at beginning and end of test.

2. If a step 4 failure occurred (see test plan in section 2), we noted the approximate number of cycles at which failure occurred.

3. We disassembled* the UUT and performed a visual inspection of all parts for any signs of distress or failure.

4. We inspected the tab spring 11753008 for conformance with red features on the drawing in figure 3.

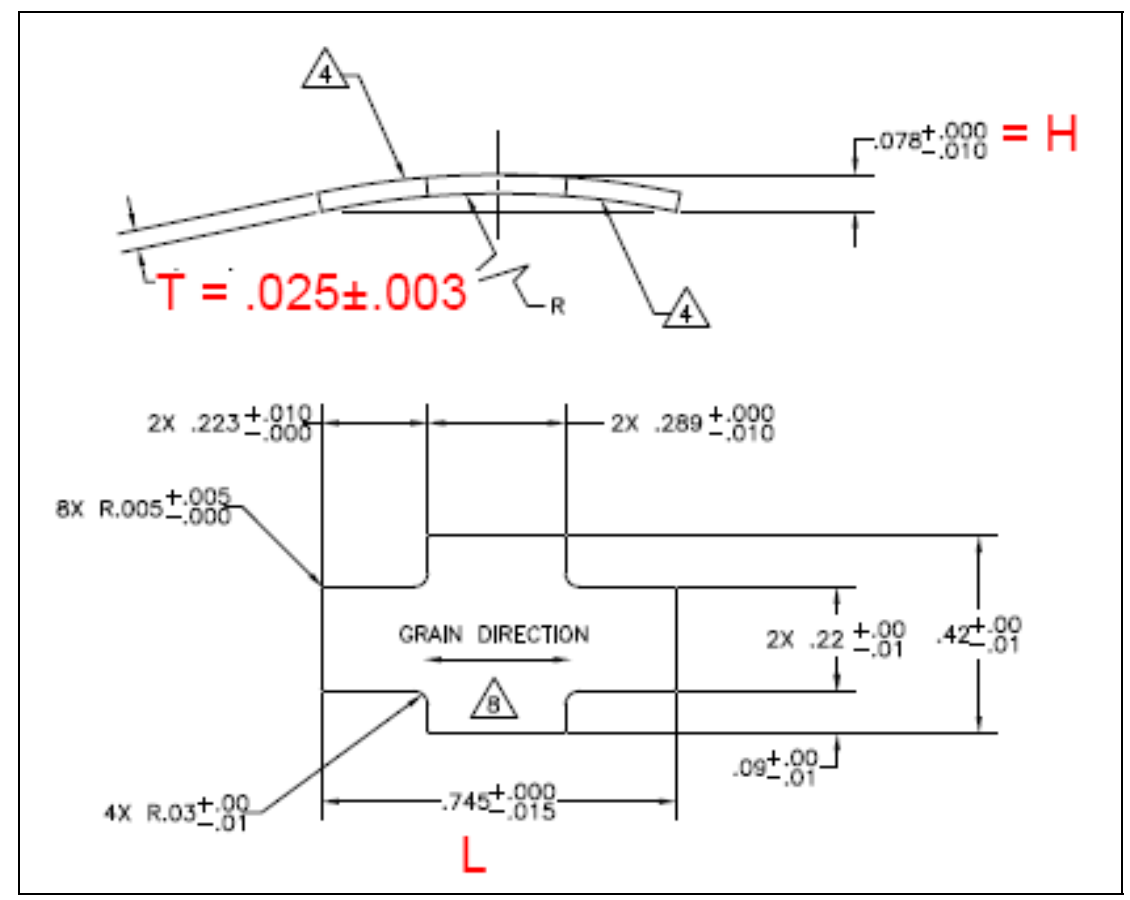

Figure 3. Drawing showing the red features we inspected.

5. We then took photos as required to support test analysis and conclusions.

\footnotetext{
*The spring pins could not be removed from the rotors so one of the trunnions had to be sawed off in order to remove the tab springs.
} 


\section{Notes on Test Hardware, Test Rationale, and Photo-documentation}

1. In order to expedite the testing, the black oxide coating, which is normally applied to the tab springs following heat treatment, was omitted as it has no effect on performance. In accordance with the pending waiver RAMS1057W (included at end of this report) allowing the use of the thinner tab springs, the glass beading was omitted and the optional dry film lubrication was applied.

2. The "Old" or "New" designation refers to the arming tab design used in the test items. The profile of the "Old" design around the pin end was creating interference with the 0.040-inthick spring; whereas, the profile of the "New" design around the pin end does not have this problem.

3. The "New" arming tabs were included in the tests to verify that the thinner tab springs were stiff enough to ensure that the "New" arming tabs would perform properly. Even though limited quantities of "New" arming tabs with the thicker tab springs have worked well, there is still the possibility that the thicker tab springs can lead to wear on the arming tabs when units are used several times. This wear can then lead to failure of the arming tab. In order to expedite the testing, it was necessary to use "New" arming tabs, which had not been hard-anodized.

4. Technical difficulties with the photo equipment resulted in a decision to proceed with testing without any pre- or during-test photo-documentation.

\section{Test Data}

This section lists the test data from the different configurations of the UUT.

\subsection{UUT 1, “Old” \#1}

1. Arming tab height at beginning and end of test:

- Beginning: 0.121 in above the hump

- End of test: 0.121 in above the hump

2. If a step 4 failure occurred, we noted the approximate number of cycles at which failure occurred:

- Failed prior to cycle 1 - the unit was 0.021 in out of specification as received. 
- The Failure is due to tolerance stackup issue of UUT parts rather than anything specific to the new tab spring.

3. Disassembly and inspection of the UUT:

- No signs of distress or failure.

4. Inspection data for tab spring 11753008 :

- $\mathrm{T}=0.022$

- $\mathrm{H}=0.065$

- $\mathrm{L}=0.747$

Figures 4 and 5 show the post-test photos from the UUT 1, "Old” \#1 test.

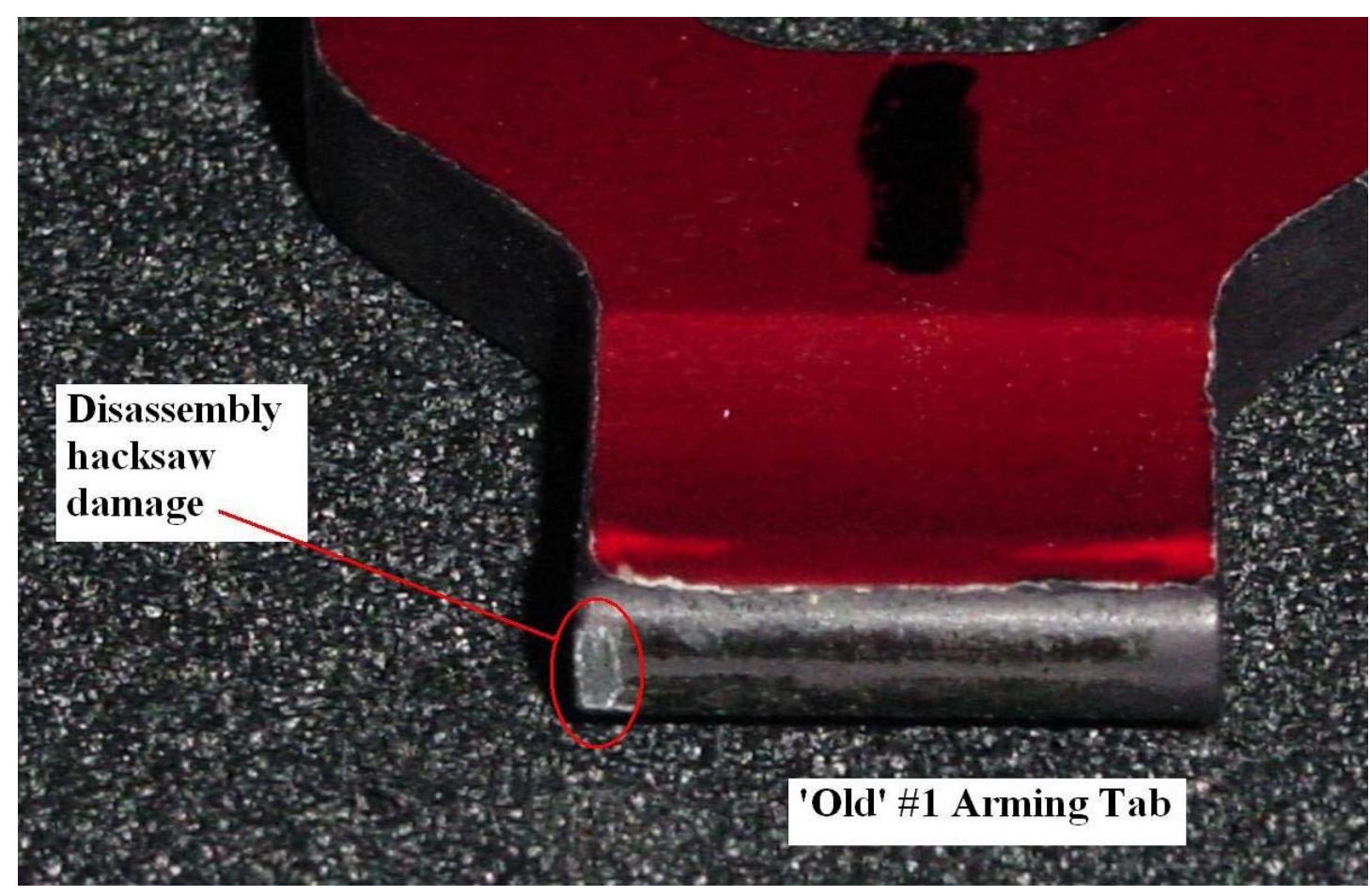

Figure 4. Post-test photo 1 for the UUT 1, “Old” \#1 test. 


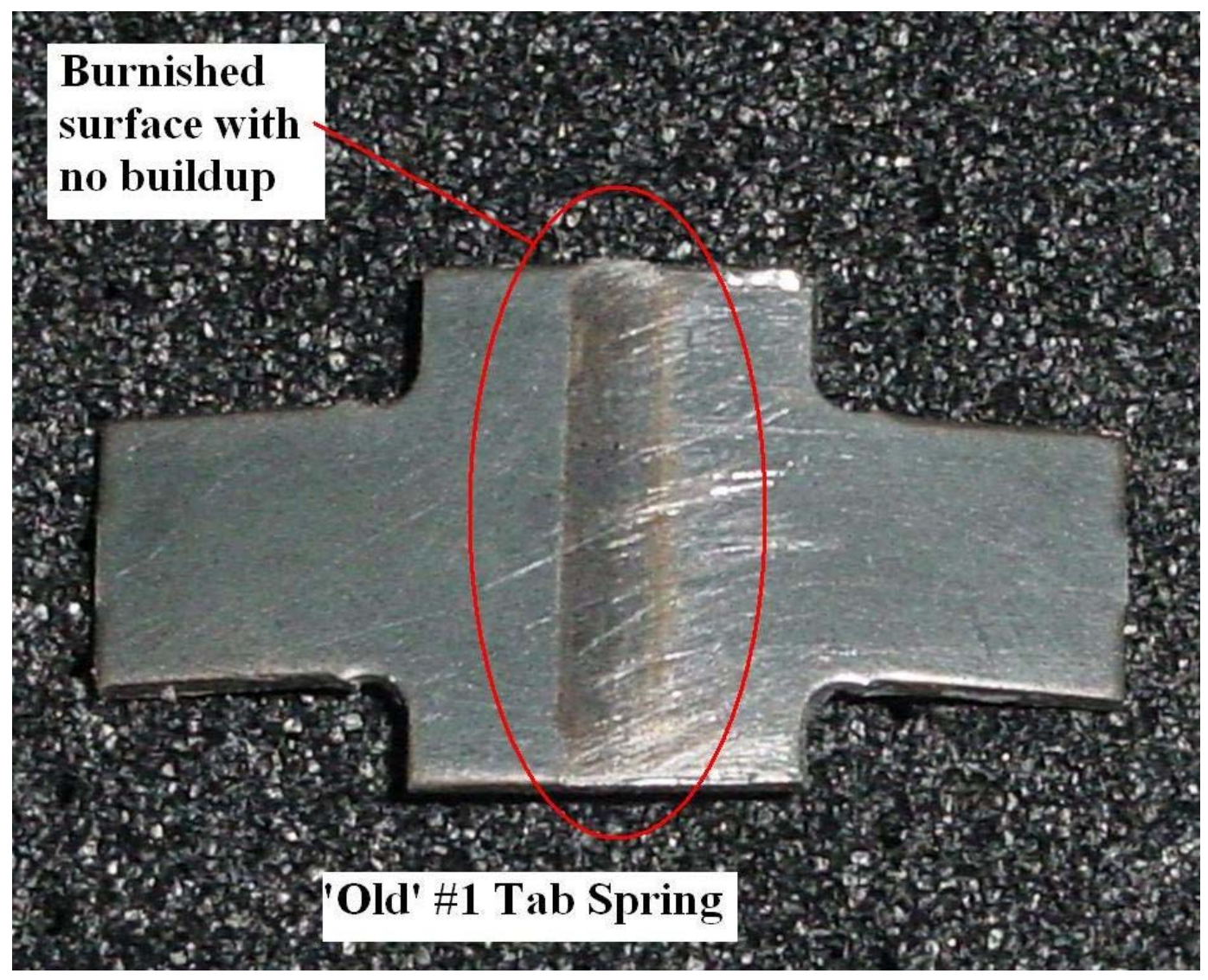

Figure 5. Post-test photo 2 for the UUT 1, “Old” \#1 test.

\subsection{UUT 2, “Old” \#2}

1. Arming Tab height at beginning and end of test:

- Beginning: 0.020 in above the hump

- End of test: 0.020 in above the hump

2. If a step 4 failure occurred, we noted the approximate number of cycles at which failure occurred:

- It did not fail.

3. Disassembly and inspection of the UUT:

- No signs of distress or failure.

4. Inspection data for tab spring 11753008 :

- $\mathrm{T}=0.022$

- $\mathrm{H}=0.067$

- $\mathrm{L}=0.743$ 
Figures 6 and 7 show the post-test photos for the UUT 2, “Old” \#2 test.

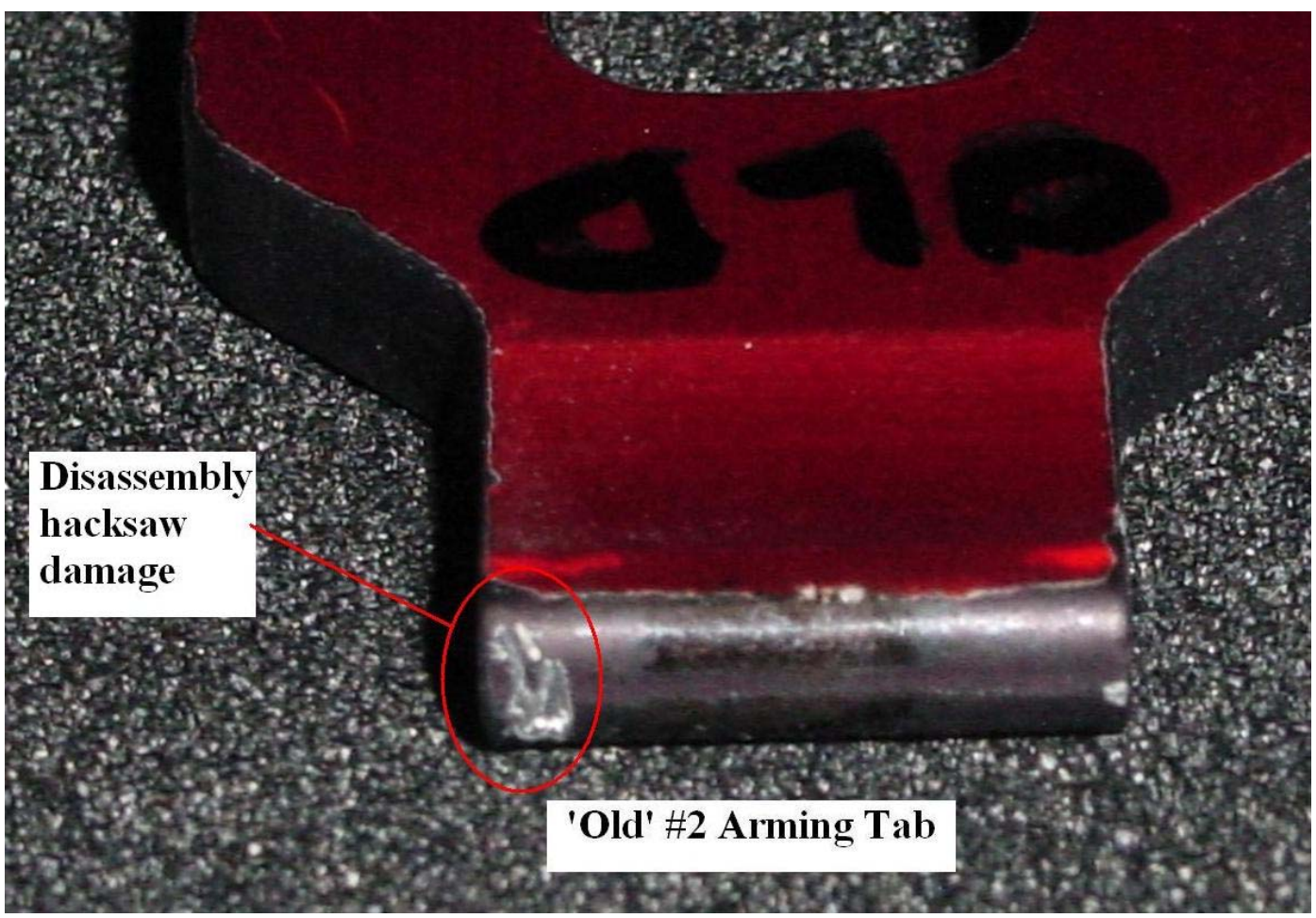

Figure 6. Post-test photo 1 for the UUT 2, “Old” \#2 test.

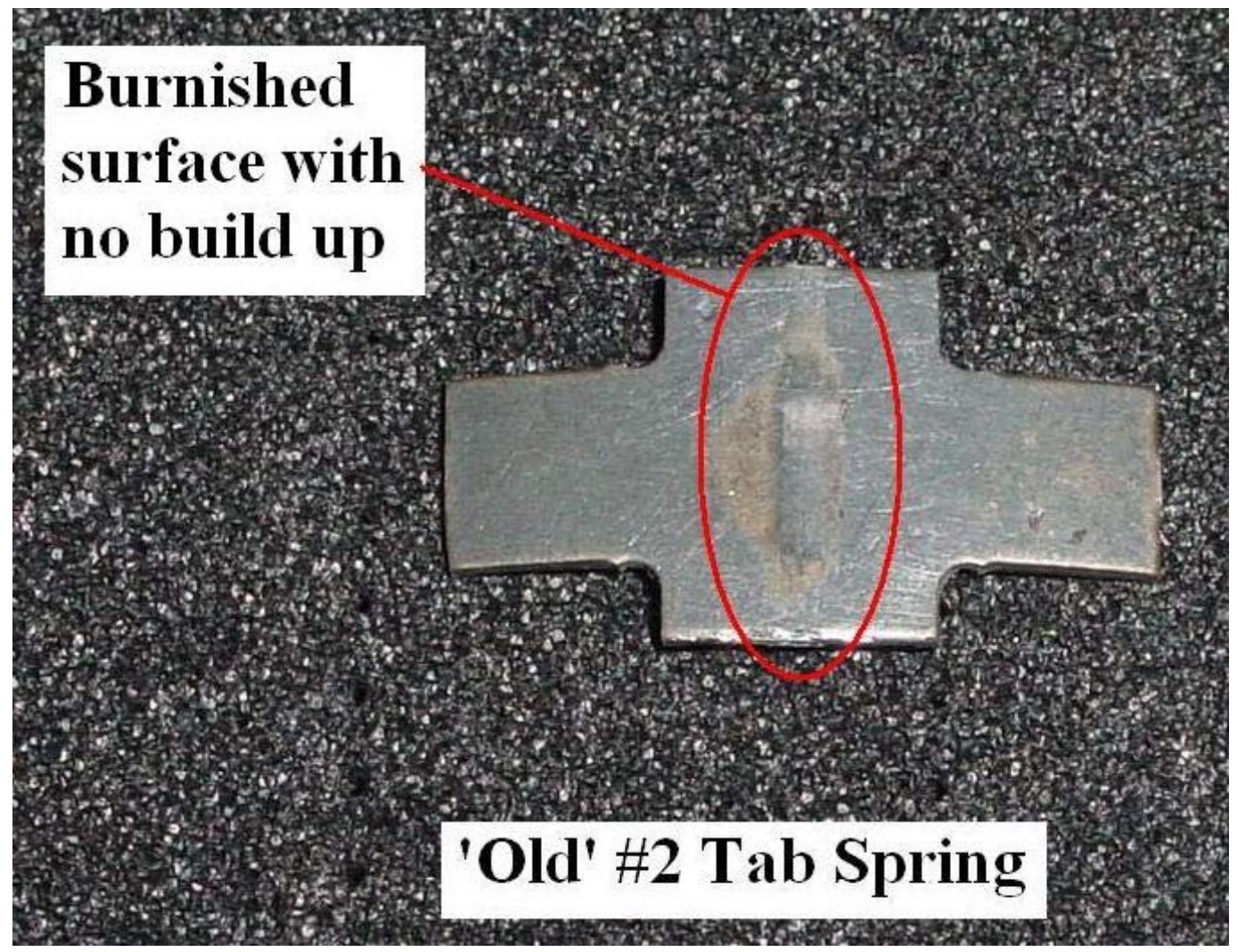

Figure 7. Post-test photo 2 for the UUT 2, "Old” \#2 test. 


\subsection{UUT 3, “New” \#1}

1. Arming tab height at beginning and end of test:

- Beginning: 0.020 in below the hump

- End of test: 0.021 in above the hump

2. If a step 4 failure occurred, we noted the approximate number of cycles at which failure occurred:

- It did not fail.

3. Disassembly and inspection of the UUT:

- No signs of distress or failure.

4. Inspection data for tab spring 11753008:

- $\mathrm{T}=0.022$

- $\mathrm{H}=0.069$

- $\mathrm{L}=0.747$

Figures 8 and 9 show the post-test photos for the UUT 3, "New” \#1 test.

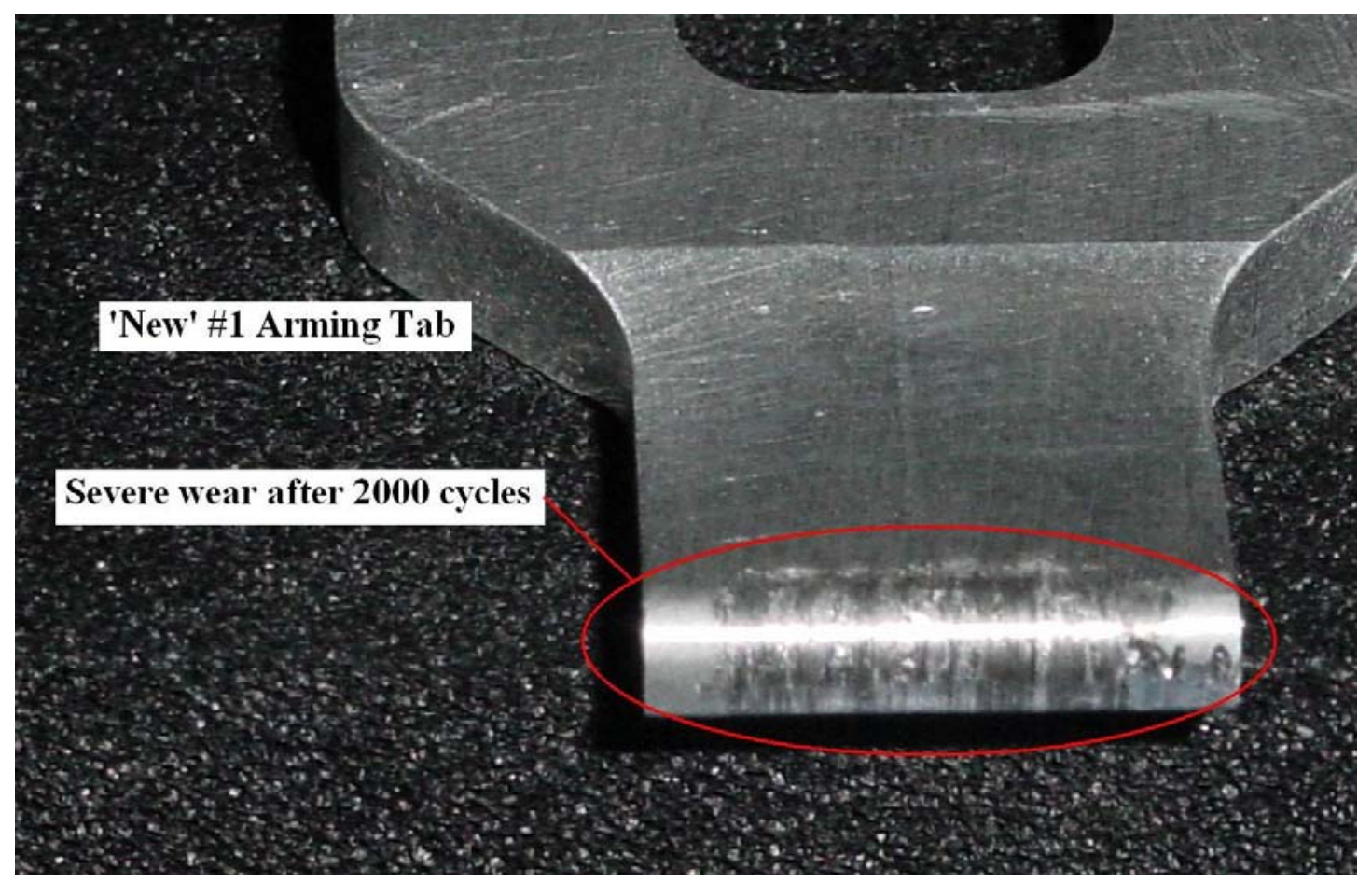

Figure 8. Post-test photo 1 for the UUT 3, “New” \#1 test. 


\section{Aluminum build-up}

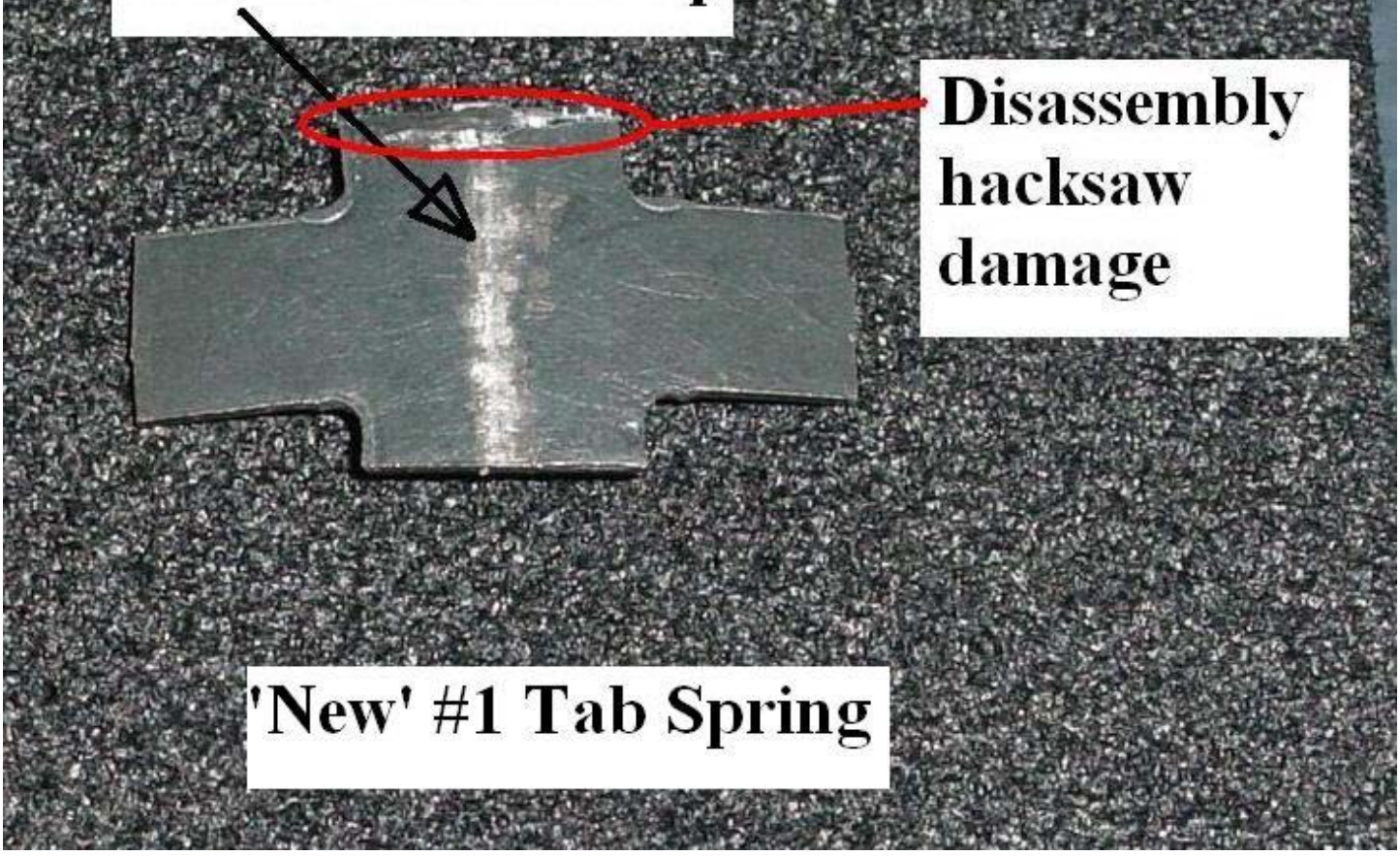

Figure 9. Post-test photo 2 for the UUT 3, “New” \#1 test.

\subsection{UUT 4, “New” \#2}

1. Arming Tab height at beginning and end of test.

- Beginning: 0.028 in below the hump

- End of test: 0.031 in above the hump

2. If a step 4 failure occurred, we noted the approximate number of cycles at which failure occurred:

- $\quad$ It did not fail.

3. Disassembly and inspection of the UUT:

- No signs of distress or failure.

4. Inspection data for tab spring 11753008:

- $\quad \mathrm{T}=0.022$

- $\mathrm{H}=0.073$

- $\quad \mathrm{L}=0.747$

Figures 10 and 11 show the post-test photos for the UUT 4, "New” \#2 test. 


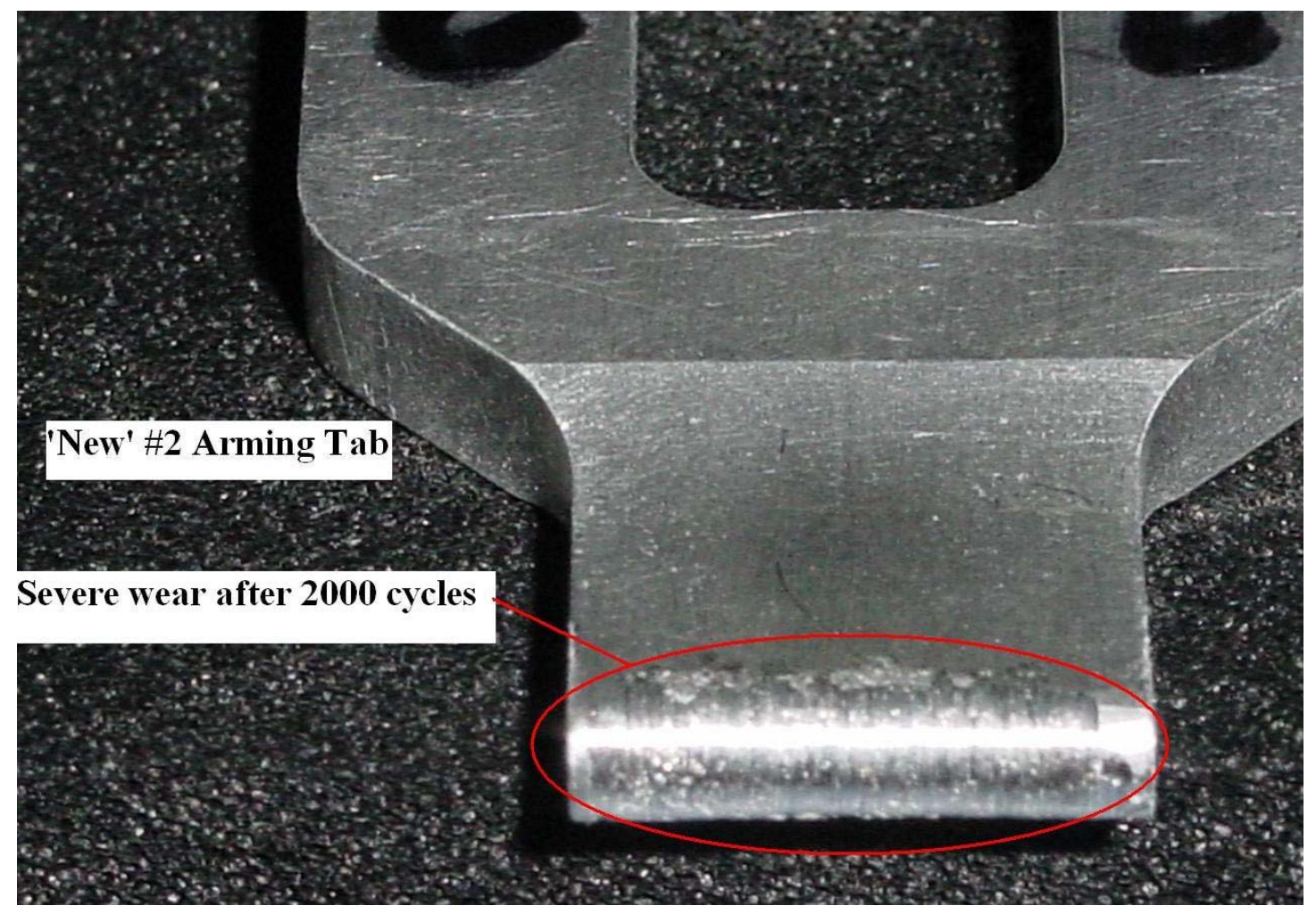

Figure 10. Post-test photo 1 for the UUT 4, "New” \#2 test.

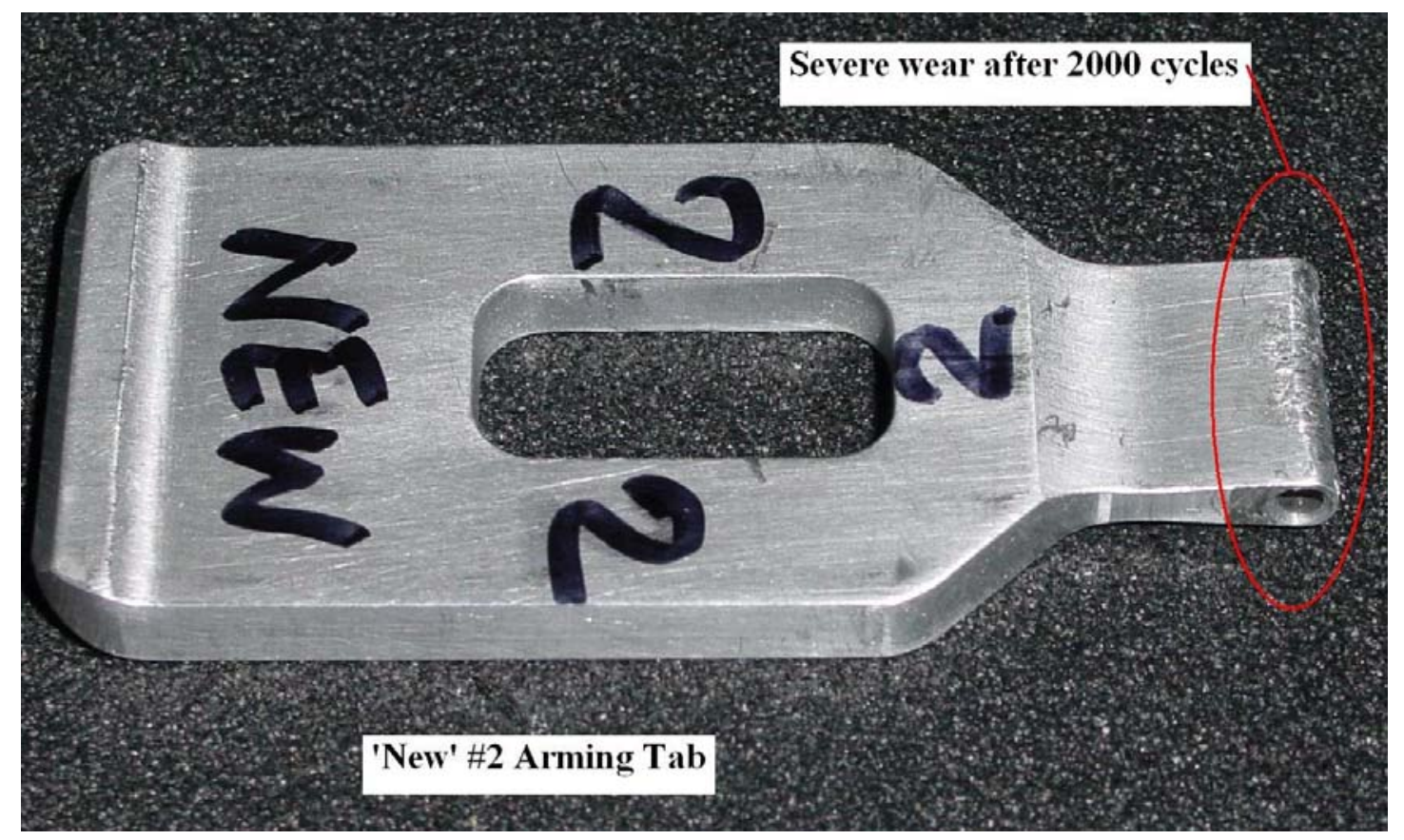

Figure 11. Post-test photo 1 for the UUT 4, “New” \#2 test. 


\section{Results and Conclusions}

\section{1 “Old” Arming Tabs with 0.025-in-thick Tab Springs}

1. The new 0.025-in-thick tab springs performed flawlessly with the "Old” arming tabs; there were no spring-related problems.

2. The "old" arming tabs with the hard-anodized finish showed no signs of wear other than some surface anomalies at the interface line where the black and red surfaces meet and some discoloration or burnishing of the entire bearing surface, which rubs against the tab spring. The tab springs from these two UUTs also had discoloration and burnishing on the bearing surface, which is centered along the crest of the curved spring.

3. The before and after height measurements of "Old" arming tabs (no change) validate the visual inspection results. The fact that one of the "Old" arming tabs failed the height limit before and after the testing will be discussed in section 8 .

4. The absence of wear supports the decision to eliminate glass beading of the tab spring surface, since this process creates a matte finish, which in the past has led to significant wear on hard-anodized arming tabs after only a few cycles. The absence of wear also supports the decision to use the dry film lubricant to improve the rotary action and prevent wear.

5. The tab spring inspection data revealed one spring that was 0.002 in too long and 0.003 in below the minimum height, and the other was 0.001 in below the minimum height. Since we have no pre-test data for these two springs, we have no way of determining if they changed during the testing or were out of spec before. In either case, they are acceptable as far as form fit and function at the next assembly level. We did get limited data from MISLUSA on a sample of five tab springs from the same build lot $(\mathrm{T}=0.024$ for all; $\mathrm{H}=0.076$, 0.076, 0.074, 0.071, and 0.068).

\section{2 “New” Arming Tabs with 0.025-in-thick Tab Springs}

1. The new 0.025-in-thick tab springs performed flawlessly with the "New" arming tabs. There were no spring-related problems and the thinner spring design provided sufficient force to maintain the arming tab in its proper position.

2. There was a significant change in the before and after height measurements of both "New" arming tabs (0.041 in for \#1 and 0.059 in for \#2). As shown in the photos (figures 8-11), this is a result of the wearing away of the bare aluminum surface of the arming tabs and the subsequent build-up of this aluminum on the bearing surface of the tab springs. Thickness measurements showed this build-up to be 0.002 inches in the areas shown in the photos. 
3. It is obvious from the test results with the hard-anodized "Old" arming tabs that this wear would not have occurred if time had been allowed for the "New" arming tabs to be hardanodized prior to testing. In spite of the wear during the testing, they both still met the height requirement.

4. The tab spring inspection data revealed both springs were 0.002 in too long. Since we have no pre-test data for these two springs, we have no way of determining if they changed during the testing or were out of spec before. In either case, they are acceptable as far as form fit and function at the next assembly level.

\section{Recommendations}

1. The 0.025-in-thick tab spring should be approved for use as stated in the proposed waiver RAMS1057W (figure 12). Thus, the glass beading operation would be eliminated and an optional dry film lubricant coating would be added. 


\section{Deviations / Waiver Form}

Oviginator Name and. Addren.

ARMY Research Labaratory

28000 Powder Mill Road

Adelphi, MD 20783

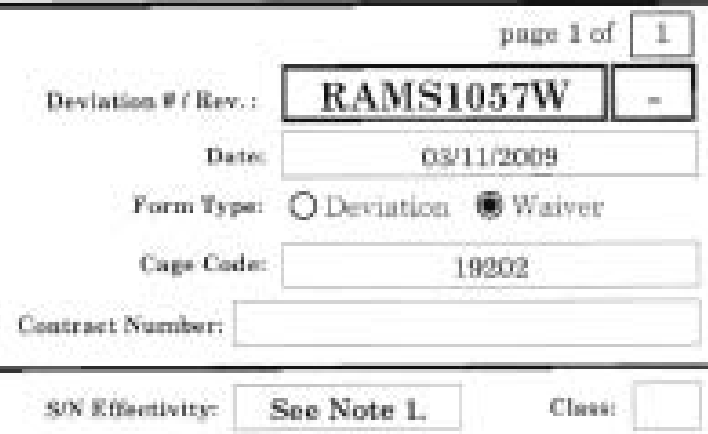

Coofieuration Inees or. Syrtem to which deviation applies

Combination Of Adopted Itema For Firing Device, Demolition, Radio Type, M152

\begin{tabular}{|c|c|}
\hline Part Effected: & 11753008 \\
\hline
\end{tabular}

Title of Decumens

SPRING, TAB

Desetizkios of Deviaclon

1. Note \#2, It is permissible to change the thickness of steel sheet from .040 stock to $.025+1 ., 003$ stock

2. Note \#5, It is permisoible to change the finish specification requirements

From: A. GLASS BEAD BLAST ENTIRE PAFT USING \#10 GLASS BBAD BLACK OXIDE COATING IAW MIL-DYTL-13924, CLASS 4.

To: A. BLACK OXIDE COATING IAW MIL-DTL-13924, CLASS 4.

B. OPTIONAL FOLLOWING A: DMA-12 DRY FILM MOLY LUBE, P/N: 85856, SAF-T-LOK INTL CORP

3. Zone C.6; It is permisible to change the thickness of steel sheet from (.040) to (.025)

Dehar Noter

Note 1. This waver shall be applicable at the discretion of the contractor and only used in conjunction with Arming Tabs per 11753004 Rev F and earlier revisions.
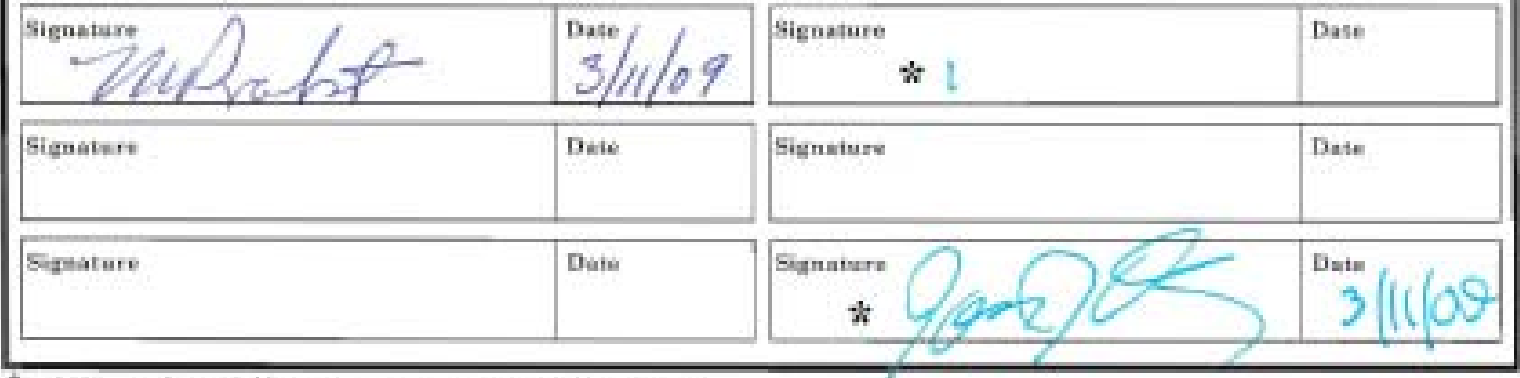

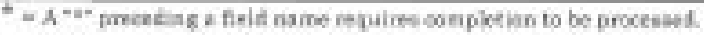

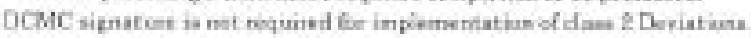

f/n: TEST PLAN_025_Spring Tab

Figure 12. Proposed waiver RAMS1057W. 
2. The proposed waiver RAMS1057W should be revised to allow the use of the 0.025-in tab spring with both the "Old" and the "New" design arming tab.

3. The waiver should be further revised to add the following caveat to apply only for use with “Old” design arming tabs:

- At the applicable higher assembly level, where the measurement is made for proper arming tab height when in the "Armed" position (0.100 in maximum above the "hump" of the Interlock Spring — see figure 13), assemblies that exceed the 0.100 in maximum limit shall be acceptable provided there is adequate overlap of the opening in the center of the arming tab with the "hump" of the interlock spring to prevent inadvertent rotation of the arming tab and rotor.

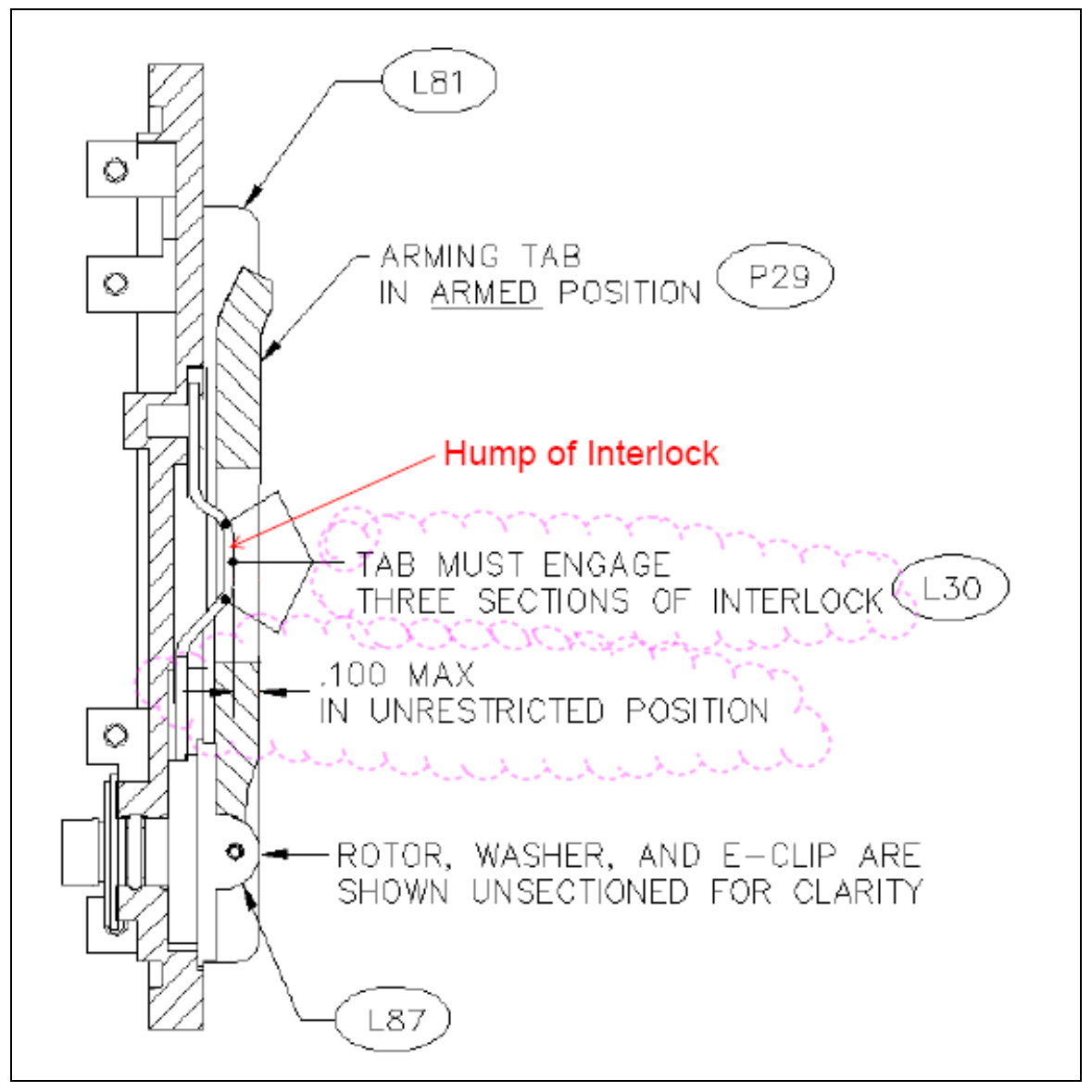

Figure 13. Diagram showing the "hump interlock” area. 
NO. OF

COPIES ORGANIZATION

$\begin{array}{cl}11 & \text { ADMNSTR } \\ \text { ELEC } & \text { DEFNS TECHL INFO CTR } \\ & \text { ATTN DTIC OCP } \\ & \text { 8725 JOHN J KINGMAN RD STE 0944 } \\ & \text { FT BELVOIR VA 22060-6218 } \\ 1 \text { CD } & \text { OFC OF THE SECY OF DEFNS } \\ & \text { ATTN ODDRE (R\&AT) } \\ & \text { THE PENTAGON } \\ & \text { WASHINGTON DC 20301-3080 } \\ & \\ & \text { US ARMY INFO SYS ENGRG CMND } \\ & \text { ATTN AMSEL IE TD A RIVERA } \\ & \text { FT HUACHUCA AZ 85613-5300 } \\ & \\ & \text { COMMANDER } \\ & \text { US ARMY RDECOM } \\ & \text { ATTN AMSRD AMR } \\ & \text { W C MCCORKLE } \\ & \text { 5400 FOWLER RD } \\ & \text { REDSTONE ARSENAL AL } \\ & \text { 35898-5000 } \\ & \text { US ARMY RSRCH LAB } \\ & \text { ATTN RDRL CIM G T LANDFRIED } \\ & \text { BLDG 4600 } \\ & \text { ABERDEEN PROVING GROUND MD } \\ & \text { 21005-5066 } \\ & \end{array}$

4 US ARMY RSRCH LAB

ATTN IMNE ALC HRR MAIL \& RECORDS MGMT

ATTN RDRL CIM L TECHL LIB

ATTN RDRL CIM P TECHL PUB

ATTN RDRL SES S M PROBST

ADELPHI MD 20783-1197

1 PROJECT MANAGER

CLOSE COMBAT SYSTEMS

ATTN SFAE AMO CCS

BLDG 183

PICATINNY NJ 07806-5000

TOTAL: 10 (1 ELEC, 1 CD, 8 HCS) 
INTENTIONALLY LEFT BLANK. 